\title{
Prospects and Opportunities in Food and Dairy Sector in India
}

\author{
Preeti Birwal* \\ Assistant Professor, Department of Food Technology, India \\ *Corresponding author: Preeti Birwal, Assistant Professor, Department of Food Technology, Jain University, India
}

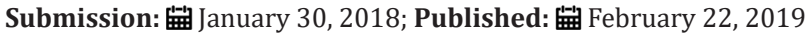

\section{Introduction}

India is world largest milk producers and one of the leader in fruits, vegetables and grains production. Various segments are there in India food and dairy industry like fruits and vegetable processing, baking, confectionary, brew industry, meat and sea foods processing, milk and milk products. Food wastage in India is major concern as wastage is on high alarm. The processing of food in proper and hygienic manner is a necessity. Also, with great change in life-life, new product development, processing, production of convenient food is high on demand. In India, the food sector is emerging with high production growth. The Indian food market is world's $6^{\text {th }}$ largest and in that $32 \%$ is dedicated to food processing only. India is largest producer of milk with digit 170MT which is $20 \%$ of global milk production and simultaneously growing at the rate of $4.8 \%$ with comparison to world growth rate which is only $2 \%$. India's dairy industry is expected to maintain a decent 16 $18 \%$ compounded annual growth over 2018-2025. This market and production were not a story of one day. Indian food industry grew step by step. From traditional farming which was limited to village level production and consuming at household level only and selling to modernization and era of co-operatives, food organized processing sector came in light in with white and green revolution.

\section{Reasons for The Good Prospects of Food Industry}

a) Urbanization has been increased in last decades and this is giving boost to food and dairy industries in India.

b) Population of India is now working in all the sectors with $24 * 7$ timings which promoting production of convenient and ready to eat products.

c) With continuous improvement in education system the living standards also have improved in the country which is resulting in demand for good and innovative food products.

d) With opening of various supermarkets consumers could be able to choose, evaluate which directly and indirectly boosting all the sectors of food industry right from the storage to packaging industry.

Food and dairy industry processing play an important role in Indian food industry. Still many sectors are not up to the mark in India. A great Potential, target and opportunity is ahead of all the entrepreneurs of India. The local market demand would support a doubling of farmer's income within the next few years. Although this objective would generate benefits in terms of employment and autonomy of food supply.

The Government of India also providing a boost to food processing sector. Foreign direct investment (FDI) incentives are being provided. The Food Safety and Standards Authority of India (FSSAI), being a major body playing a premium role in making food testing infrastructure strong. The Indian Council for Fertilizer and Nutrient Research (ICFNR), Ministry of Food Processing Industries (MoFPI), also contributing in majorly.

The opportunities in food and dairy enterprise could be classified in segment like production of food commodities i.e. farming, processing, production plants, retailer, supplier and the manufacturer of the machinery and feed for the animals. In short one has to understand following point for starting an enterprise are like raw food is having short shelf-life, the varying production volume season wise. Different production and processing systems around the India. Risk of spoilage during transportation.

There is great potential in dairy and food business. Industry is a flexible, where innovations with number experiments in probiotic, fermented, fortified, ready to cook, ready to serve, ready to eat, ready to pack, dried, retort, UHT products could be generated and could become a key for selling the products. One should see the potential, should understand the chemistry, microbiology and processing of all food commodities. Wonders could be happened in food and dairy products industries. 

(C) (P) $\begin{aligned} & \text { Creative Commons Attribution } 4.0 \\ & \text { International License }\end{aligned}$

For possible submissions Click Here

Submit Article

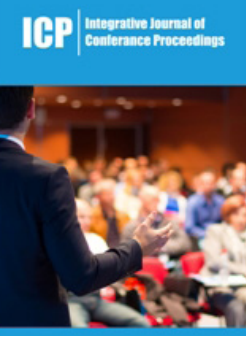

Integrative Journal of Conference Proceedings

\section{Benefits of Publishing with us}

- High-level peer review and editorial services

- Freely accessible online immediately upon publication

- Authors retain the copyright to their work

- Licensing it under a Creative Commons license

- Visibility through different online platforms 